Д. О. Пупков

Одеська національна академія харчових технологій, вул. Канатна, 112, Одеса, 65039, Україна

\title{
ПЕРЕНОСНИЙ ПАРАБОЛОЦИЛІНДРИЧНИЙ СОНЯЧНИЙ НАГРІВАЧ ХАРЧОВИХ ПРОДУКТІВ
}

В роботі представлено розробку параболочиліндричного сонячного нагрівача, призначеного для приготування та розігріву харчових продуктів, з використанням сонячної енергії. Конструкція складається з рефлектора, у вигляді параболочиліндричної лінзи, і приймача у вигляді шампура для харчових продуктів. Рефлектор виконаний з гнучких матеріалів, але водночас може мати перевагу в стійкості до зовнішніх впливів. Завдяки простій конструкиії кріплення є можливість збирати нагрівач в простий креслярський тубус, вага якого не перевищує трьох кілограмів, щзо робить пристрій зручним для транспортування та у використанні. Це спеціальний пристрій, завдяки якому вдається сконцентрувати сонячне випромінювання в необхідній точці та досягти необхідних температур, придатних для розігріву і приготування харчових продуктів. Показана зручна конструкція нагрівача та представлені особливості розрахунків основних геометричних параметрів параболо-циліндричного сонячного нагрівача. Також наведено порівняння з існуючими прототипами.

Ключові слова: Параболоциліндричний; Рефлектор; Апертура; Сонячна інсоляція; Короткофокусні, середньофокусні, довгофокусні дзеркала.

\section{Д. О. Пупков}

Одесская национальная академия пищевых технологий, ул. Канатная, 112, Одесса, 65039, Украина

\section{ПЕРЕНОСНОЙ ПАРАБОЛОЦИЛИНДРИЧЕСКИЙ СОЛНЕЧНЫЙ НАГРЕВАТЕЛЬ ПРОДУКТОВ ПИТАНИЯ}

В работе представлена разработка параболочилиндрического солнечного нагревателя, предназначенного для приготовления и разогрева продуктов питания, с использованием солнечной энергии. Конструкиия состоит из рефлектора в виде параболоцилиндрической линзы, и приемника в виде шампура для пищевых продуктов. Рефлектор выполнен из гибких материалов, но одновременно может иметь преимущество в устойчивости к внешним воздействиям. Благодаря простой конструкиии крепления есть возможность собирать нагреватель в простой чертежный тубус, вес которого не превышает трех килограммов, что делает устройство удобным для транспортировки и в использовании. Это специальное устройство, благодаря которому удается сконщентрировать солнечное излучение в требуемой точке и достичь необходимых температур, пригодных для разогрева и приготовления пищевых продуктов. Показана удобная конструкция нагревателя и представлень особенности расчетов основных геометрических параметров параболоцилиндрического солнечного нагревателя. Также приведено сравнение с существующими прототипами.

Ключевые слова: Параболочилиндрический; Рефлектор; Апертура; Солнечная инсоляция; Короткофокусные, среднефокусные, длиннофокусные зеркала.

This work is licensed under the Creative Commons Attribution International License (CC BY). http://creativecommons.org/licenses/by/4.0/

\section{ВСТУП}

Сьогодні особлива увага приділяється розвитку поновлюваних джерел енергії. Серед величезної безлічі подібних ресурсів промениста енергія Сонця грає одну з провідних ролей. Її використання у виробництві та побуті, враховуючи повсюдну поширеність і екологічність, представляється найбільш перспективним і зручним. Величина сонячної інсоляції для помірних широт становить від 800 до 1000 Вт/м². Тобто, якщо ми маємо плоску площадку, звернену до Сонця перпендикулярно його променям, то на $1 \mathrm{~m}^{2}$ цієї поверхні буде надходити приблизно 1 кВт теплової енергії
- пропорційно потужності однієї конфорки електропечі. Цю енергію можна використовувати, наприклад, для нагріву теплоносія в сонячних колекторах або для теплової обробки харчових продуктів у так званих сонячних печах (кухнях). Сонячний концентратор для приготування продуктів відноситься до сонячних печей, в яких основним робочим елементом є дзеркалоконцентратор. За певних геометричних розмірах апертури параболоциліндричного дзеркала вдається досягти температур придатних для розігріву та приготування напівфабрикатів і т.п.

Розроблена особлива конструкція дзеркала, заснована на використанні гнучких матеріалів, що зру- 
чно використовувати. Такий вид приготування їжі на перший погляд $\epsilon$ дуже незвичайним, але водночас $\epsilon$ дуже зручним. Він відрізняється від приготування традиційних страв на мангалі. Такий спосіб набагато дешевший і не вимагає тривалого підготування для початку роботи, достатньо тільки розкласти і підготувати концентратор до роботи, що потребує значно менше часу i ресурсів, ніж приготування на «традиційному» мангалі. За своєю вартістю установка коштує не набагато дорожче, ніж мангал та комплектуючі до нього, однак, вимагає кваліфікованої роботі при його виготовленні.

\section{I. ІСНУЮЧІ СОНЯЧНІ КОНЦЕНТРАТОРИ}

Сонячний концентратор являє собою оптичний пристрій у вигляді лінз або дзеркал, де забезпечується збільшення щільності потоку сонячного випромінювання.

Фокусуючі концентратори (колектори) застосовують дзеркальні поверхні, щоб накопичувати сонячну енергію на спеціальному поглиначі - «теплоприймачі». Температура, властива цьому обладнанню, набагато більша, ніж на плоских колекторах, але вони здатні концентрувати виключно сонячне пряме випромінювання, що є причиною поганих показників у хмарну або туманну погоду. Наявність дзеркальної поверхні надає можливість сфокусувати сонячне світло, яке відображається 3 великої поверхні, на невелику поверхню абсорбера, за рахунок чого можна домогтися високої температури. У різних моделях концентраторів випромінювання Сонця може концентруватися в фокусній точці або в уздовж фокальної тонкої лінії.

\section{1 Сонячні печі}

Успішне використання сонячних печей (плит) відзначалося в Свропі та Індії ще у XVIII-му столітті. Сонячні плити та духові шафи поглинають сонячну енергію, перетворюючи ії на тепло, яке накопичується всередині замкнутого простору. Поглинуте тепло використовується для варіння, смаження і випічки. Температура в сонячній печі може досягати 200 градусів за шкалою Цельсія.

Сонячні печі бувають різних форм і розмірів. Наведемо кілька прикладів: духова шафа, пічконцентратор, рефлектор, сонячний пароварочний апарат і т.П. При всій різноманітності моделей, всі печі уловлюють тепло і утримують його в теплоізольованій камері. У більшості моделей сонячне світло безпосередньо впливає на їжу.

\section{2 Ящикові сонячні печі}

Ящикові сонячні печі складаються 3 добре ізольованою коробки, пофарбованої всередині в чорний колір, в яку поміщають чорні каструлі з їжею (рисунок 1). Коробка накривається двошаровим "вікном", яке пропускає сонячне випромінювання в ящик і утримує тепло всередині. Додатково до нього кріпиться кришка 3 дзеркалом на внутрішній стороні, яка, будучи відкинутою, підсилює падаюче випромі- нювання, а в закритому вигляді покращує теплоізоляцію печі.

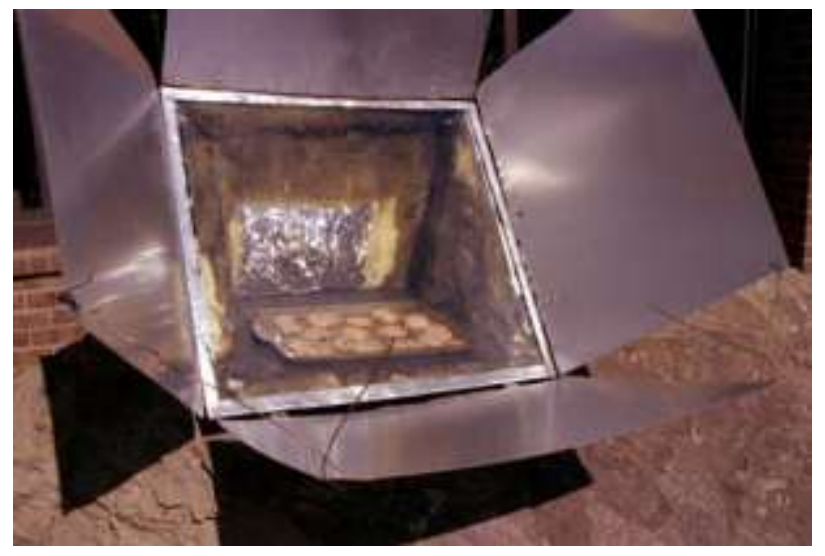

Рисунок 1 - Ящикова сонячна піч

Основні переваги ящикових сонячних печей: - використовують як пряме, так і розсіяне сонячне випромінювання;

- у них можна нагрівати одночасно кілька каструль;

- вони легкі, портативні і прості в обігу;

- їх не потрібно повертати слідом за сонцем;

- помірні температури роблять помішування не обов'язковим;

- їжа залишається теплою цілий день;

- їх легко виготовити і відремонтувати, використовуючи місцеві матеріали;

- вони відносно недорогі (порівняно з іншими типами сонячних печей).

Притаманні їм, звичайно, і деякі недоліки:

- $з$ їх допомогою можна готувати тільки в денний час; - через помірні температури на приготування їжі потрібен тривалий час;

- скляна кришка призводить до значних втрат тепла;

- такі печі "не вміють" смажити.

Завдяки своїм перевагам, сонячні печі-ящики є найбільш поширеним видом сонячних печей. Вони бувають різних видів: промислового виробництва, кустарні і саморобні; формою можуть нагадувати плоский валізку або широкий низький ящик. Бувають і стаціонарні печі, зроблені з глини, з горизонтально розташованої кришкою (у тропічних і субтропічних районах) або похилій (в помірному кліматі). Для сім'ї 3 п'яти чоловік рекомендуються стандартні моделі 3 площею апертури (вхідний площі) близько 0,25 м². У продажу зустрічаються і більші варіанти печей - $1 \mathrm{~m}^{2} \mathrm{i}$ більше.

\section{3 Дзеркальні печі}

Найпростіша дзеркальна піч являє собою параболічний рефлектор і підставку для каструлі, розташовану у фокусі печі. Якщо піч виставлена на Сонці, то сонячне світло відбивається від всіх рефлекторів в центральну точку (фокус), нагріваючи каструлю. Рефлектор може являти собою параболоїд, виготовлений, наприклад, з листової сталі або фольги, що відбиває. Відбиває поверхня зазвичай виготовлена 3 полірованого алюмінію, дзеркального металу або пластику, але може складатися також з безлічі маленьких плос- 
ких дзеркал, прикріплених до внутрішньої поверхні параболоїда. Залежно від потрібного фокусної відстані, рефлектор може мати форму глибокої миски, в яку повністю занурюється каструля з їжею (коротке фокусна відстань, посуд захищена від вітру) або дрібної тарілки, якщо каструля встановлюється в фокусної точці на певній відстані від рефлектора.

Всі печі-відбивачі використовують тільки пряме сонячне випромінювання, $\mathrm{i}$

тому повинні постійно повертатися за Сонцем. Це ускладнює їх експлуатацію, тому що ставить користувача в залежність від погоди і регулюючого пристрою.

Переваги дзеркальних печей:

- здатність досягати високих температур і, відповідно, швидке приготування їжі;

- відносно недорогі моделі;

- деякі з них можуть служити також для випічки.

Перерахованих достоїнств супроводжують і деякі недоліки:

- залежно від фокусної відстані, піч повинна повертатися за сонцем приблизно кожні 15 хвилин;.

- використовується тільки пряме випромінювання, а розсіяне сонячне світло втрачається;

- навіть при невеликій хмарності можливі великі втрати тепла;

- звернення $з$ такою піччю вимагає певного досвіду і розуміння принципів іiі дії;

- відбите рефлектором випромінювання дуже яскраве, сліпить очі, і може призвести до отримання опіку при контакті з фокальною плямою;

- приготування їжі обмежується денними годинами;

- кухареві доводиться працювати на спекотному сонці (за винятком печей з фіксованим фокусуванням);

- ефективність печі у великій мірі залежить від мінливої сили і напряму вітру;

- блюдо, приготоване вдень, до вечора вистигає.

Складність поводження 3 цими печами в поєднанні 3 тим фактом, що кухар змушений стояти на сонці, є головною причиною їх невисокої популярності. Але в Китаї, де приготування їжі традиційно вимагає високої температури і потужності, вони широко поширені.

\section{ІІ. КОНСТРУКЦІЯ ПЕРЕНОСНОГО ПАРАБОЛО- ЦИЛІНДРИЧНОГО СОНЯЧНОГО НАГРІВАЧА ХАРЧОВИХ ПРОДУКТІВ}

Переносний Параболоциліндричний сонячний нагрівач харчових продуктів (далі ПСН) призначений для приготування їжі за допомогою променевої енергії сонця. ПСН складається з рефлектора, фікусуючих шайб і спиць, системи ніжок, штирьків і шампура для продукту (рисунок 2).

Рефлектор 1 - основний робочий елемент конструкції, що представляє собою параболоциліндричне дзеркало певної кривизни. Задана кривизна підтримується зверху і знизу фокусуючими спицями 3, на кінцях яких є засувки 8,3 їх допомогою спиці кріпляться до рефлектора (рисунок 3 ).

На протилежних кінцях спиць нагвинчені кульки 11, які фіксуються в гнізда верхньої та нижньої фокусуючих шайб 2. Із гнізд фокусуючих шайб прорізані жолобки 12, направляючі і фіксують спиці під потрібним кутом. Сполуки шайб і спиць працюють як кульові шарніри, що забезпечує їх складання в похідному положенні (рисунок 4). Фокусуючі шайби також утримують шампур 3 продуктом 6 уздовж лінійного фокусу рефлектора. Ніжки-штирі 4 служать опорами для всієї конструкції. Ними також регулюється орієнтація на сонці. Верхніми кінцями за допомогою кембриків 9 ніжки рухомо кріпляться до рефлектора, а нижні кінці встромлюють в гр.

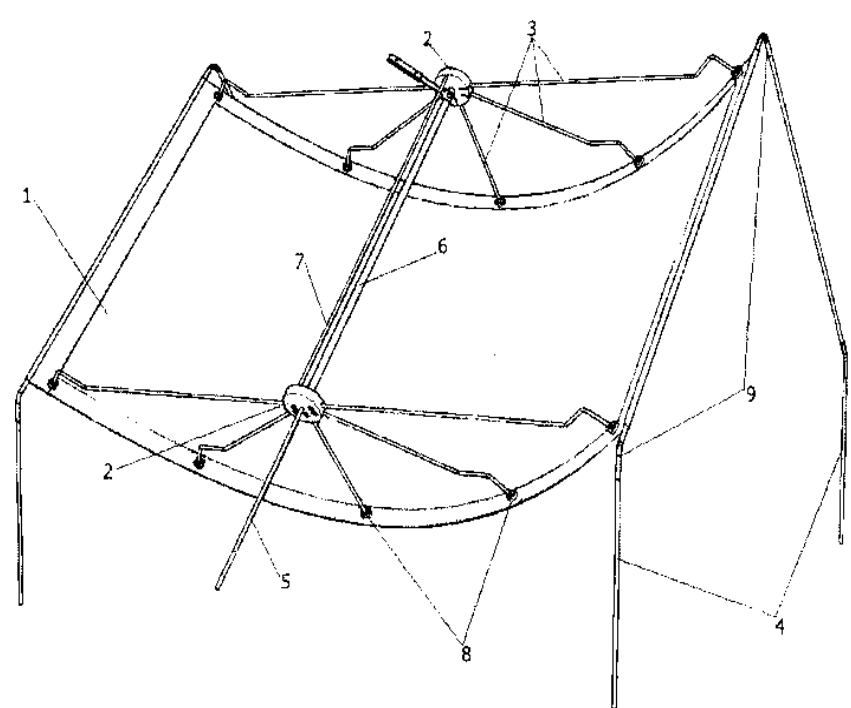

1 - рефлектор, 2 - фокусують шайби, 3 - фокусуючі спиці, 4 - ніжки-итирі, 5 - итирок, 6 - шампур, 7 розпірка між фокусуючими шайбами, 8 -засувки, 9 з'єднувальні кембрики

Рисунок 2 - Переносний параболочиліндричний сонячний нагрівач харчових продуктів

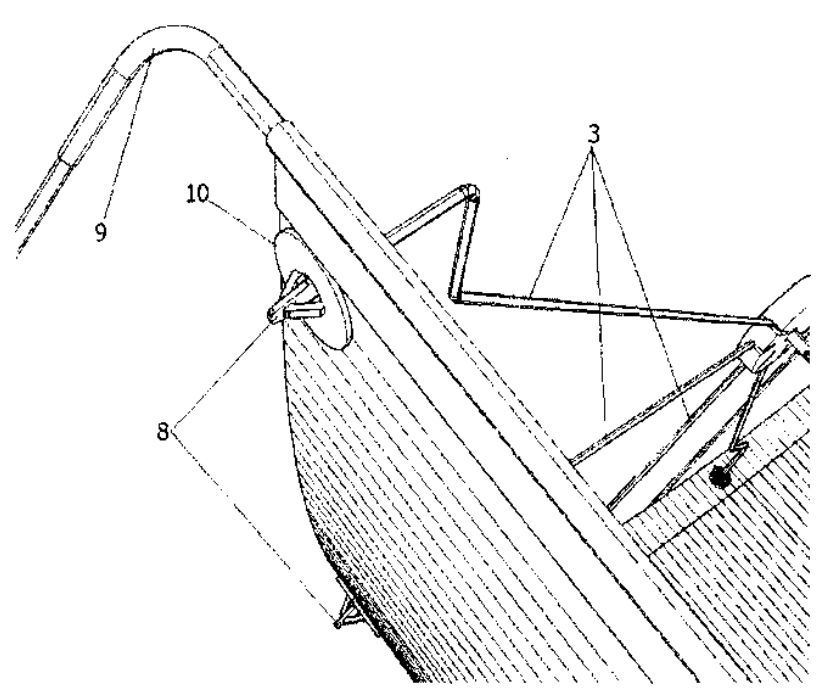

3 - фокусуючі спиці, 8-засувки, 9 - з'єднувальні кембрики, 10 - посилюючі шайби під засувки

\section{Рисунок 3 - 3'єднання спиць з рефлектором}



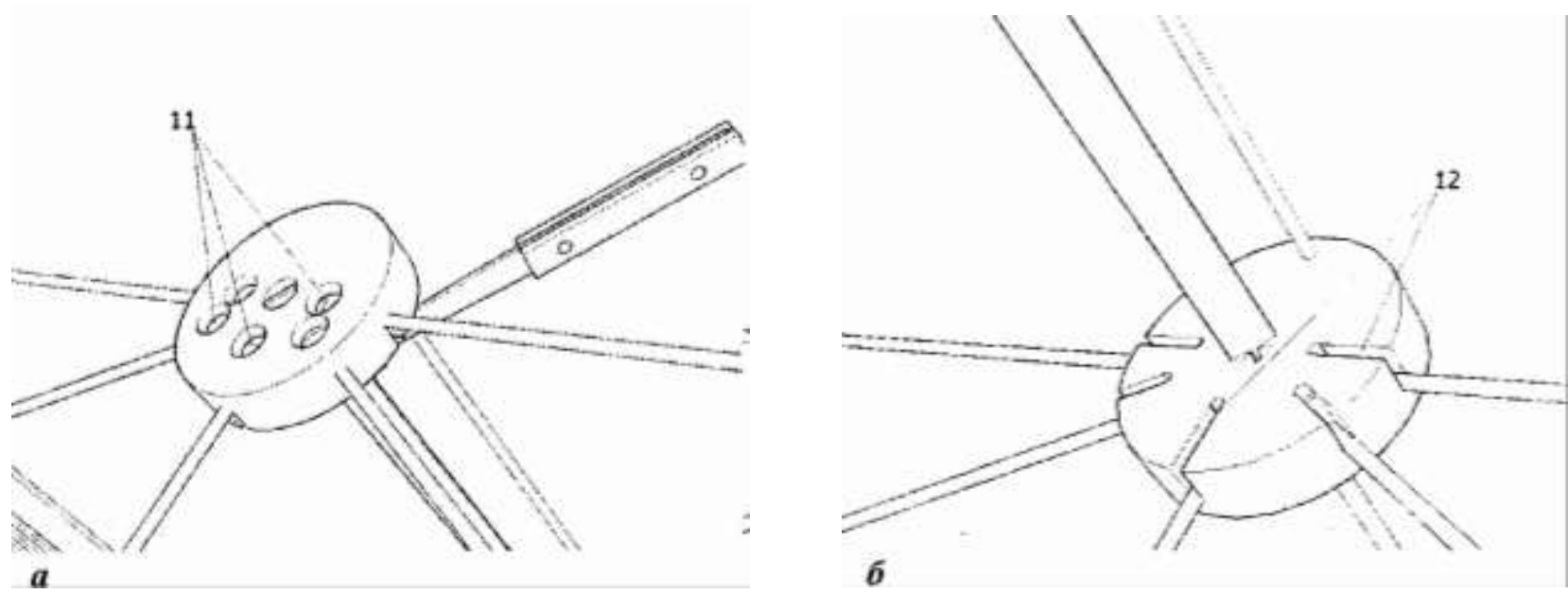

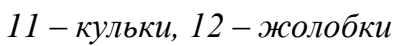

Рисунок 4 - Верхня (а) і нижня (б) фокусуючі шайби

\section{III. РОЗРАХУНОК ГЕОМЕТРИЧНИХ ПАРАМЕТ- РІВ ПАРАБОЛОЦИЛІНДРИЧНОГО ДЗЕРКАЛА}

При розробці ПСН в першу чергу орієнтуються на величину потоку сонячного випромінювання, що уловлюється (передбачувану потужність ПСН). Вона визначається площею $P$ апертури дзеркальної частини рефлектора $P=M_{1} M_{1} h$, яка розраховується як добуток діаметра розкриву параболи $\mathrm{M}_{1} \mathrm{M}_{1}$ на висоту $h$ циліндра, і величиною сонячної інсоляції на місцевості, де використовується ПСН. Розмір вибирається 3 урахуванням довжини шампура. Наприклад, довжина шампура $\mathrm{h}=0,6 \mathrm{M}$, діаметр розкриву задаємо ним $M_{1} M_{1}=1 \mathrm{M}$, сонячна інсоляція $\mathrm{I}=800 \mathrm{BT} / \mathrm{M} 2$, тоді:

$$
\begin{aligned}
& P=M_{1} M_{1} * h=0.6 * 1=0.6 \mathrm{~m}^{2} \\
& Q=P * I=0.6 * 800=480 \mathrm{BT}
\end{aligned}
$$

Поперечний переріз рефлектора являє собою параболу - геометричне місце точок, рівновіддалених від даної прямої (директриси параболи) і даної точки (фокусу параболи). Канонічне рівняння параболи: $y^{2}=2 * P * X$. У ПСН використовується оптична властивість параболи, яка формулюється так: пучок променів, паралельних осі параболи, відбиваючись у параболі, збирається в їі фокусі. Саме у фокусі розташовується опромінюваний об'єкт, у нашому випадку шампур з продуктом.

Спочатку задаємося основними геометричними параметрами параболи, а саме - діаметром розкриву i кутом полурозкриву параболи (або діаметром розкриву і положенням фокусу вздовж осі симетрії параболи). Зв'язок між цими величинами виражається формулою:

$$
F=\frac{p}{2} * M M^{\prime} \frac{1+\cos \alpha}{4 \sin \alpha}
$$

Змінюючи розмір F можна отримати короткофокусні (кут розкриву $\alpha>90^{\circ}$ ), середньофокусні (кут розкриву $\alpha=90^{\circ}$ ), і довгофокусні (кут розкриву $\alpha<90^{\circ}$ ) параболічні дзеркала (рисунок 6). Усі вони мають різну потужність, що припадає на одиницю площі теплоприймача (продукту), і в різній мірі чутливі до орієнтації на сонці.

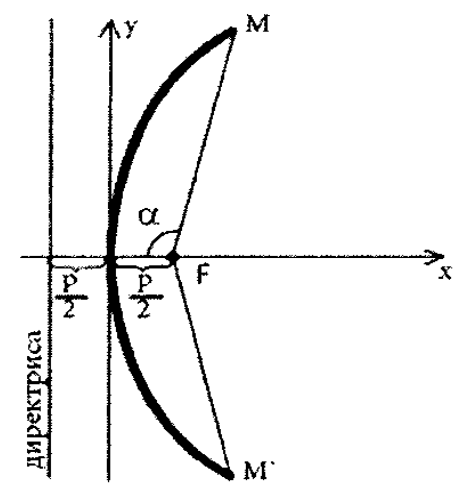

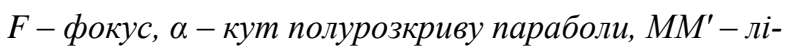
нійний діаметр параболи, $p$ - параметр параболи (відстань від фокуса до директриси параболи)

Рисунок 5 - Парабола в декартових координатах
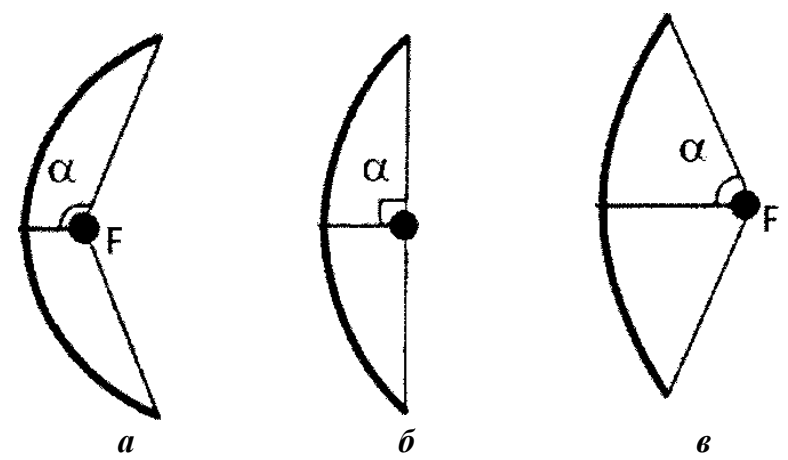

Рисунок 6 - Варіанти параболічних дзеркал: короткофокусне (а), середньофокусне (б), довгофокусне (в).

Довжина відрізка FM обчислюється як відстань від фокуса до точки М 3 координатами $(\mathrm{x} ; \mathrm{y})$ 


$$
F M=\sqrt{\left(\frac{p}{2}-y\right)^{2}+x^{2}}
$$

Лінійний діаметр параболи ММ:

$$
M M=2 *\left[\sqrt{x\left(x+\frac{p}{2}\right)}+\frac{p}{2} \operatorname{arsh} \sqrt{\frac{2 x}{p}}\right]
$$

Враховуючи, що рефлектор виготовлений з гнучких матеріалів, для підтримки необхідної кривизни можуть знадобитися додаткові фокусуючі спиці. Їх розраховують виходячи 3 властивості, що всі параболи подібні. Відстань між фокусом і директрисою визначає масштаб.

\section{Короткофокусне параболоциліндричне дзеркало}

Був виготовлений робочий зразок ПНС 3 короткофокусним рефлектором під довгий шампур $h=600$ мм, з кутом полурозкриву, лінійним діаметром. Вирішимо задачу зворотною методикою. Спираючись на властивості параболи запишемо вирази для MF i FD:

$$
\left\{\begin{array}{l}
M F=x+\frac{p}{2} \\
F D=x-\frac{p}{2}
\end{array}\right.
$$

У трикутнику $\triangle F M D$ :

$$
\begin{aligned}
& F D=M F \cos 60^{\circ}, \\
& \frac{p}{2}=\frac{x}{3} .
\end{aligned}
$$

Заміняємо $\frac{p}{2}$ на $\frac{x}{3}$ у формулі (5):

$$
\begin{aligned}
& M M=2\left[\sqrt{x\left(x+\frac{x}{3}\right)}+\frac{x}{3} \operatorname{arsh} \sqrt{3}\right]=2\left[\frac{x}{3} *(2 \sqrt{3}+\operatorname{arsh} \sqrt{3})\right] \\
& 1200=2 *\left[\frac{x}{3} *(2 \sqrt{3}+\operatorname{arsh} \sqrt{3})\right] \\
& x \approx 376,5 \mathrm{MM} \\
& \frac{p}{2}=\frac{376,5}{3}=125,5 \mathrm{MM} \\
& F M=376,5+125,5 \approx 502 \mathrm{MM}
\end{aligned}
$$
ли (3):

Діаметр розкриву параболи знаходимо з форму-

$$
M M^{\prime}=\frac{p}{2} * \frac{4 \sin \alpha}{1+\cos \alpha}=125,5 * \frac{4 \sin 120^{\circ}}{1+\cos 120^{\circ}}=869,5 \mathrm{MM} \text {. }
$$

\section{Середньофокусне параболоциліндричне дзеркало}

Робочий зразок виготовлявся 3 матеріалу іншої довжини. Для даного варіанту кут полурозкриву $\alpha=90^{\circ}$ (рисунок 7). MP $=\mathrm{MD}$, отже, формула (5) приймає вигляд:

$$
\begin{aligned}
& M M=2\left[\sqrt{\frac{p}{2}\left(\frac{p}{2}+\frac{p}{2}\right)}+\frac{p}{2} \operatorname{arsh} \sqrt{\frac{2 p}{2 p}}\right]=2\left[\frac{p}{2}(\sqrt{2}+\operatorname{arsh} \sqrt{1})\right] \\
& 1162=2\left[\frac{p}{2}(\sqrt{2}+\operatorname{arsh} \sqrt{1})\right] \\
& \frac{p}{2}=\frac{1162}{2(\sqrt{2}+\operatorname{arsh} 1)} \approx 253,1 \mathrm{MM} \\
& F M=y=\sqrt{2 p x}=\sqrt{2(253,1 \cdot 2) \cdot 253,1}=506,2 \mathrm{MM} \\
& M M=2 F M=2 \cdot 506,2=1012,4 \mathrm{MM} .
\end{aligned}
$$

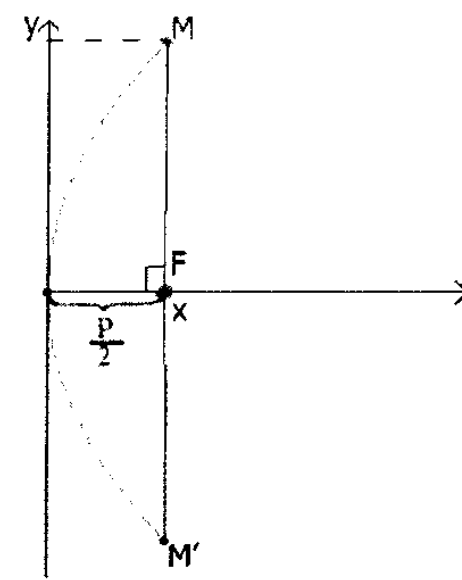

Рисунок 7 - Схема середньофокусного параболоциліндричного дзеркала

\section{Довгофокусне параболоциліндричне дзеркало}

Схема довгофокусного параболо циліндричного дзеркала наведена на рисунку 8. Спираючись на властивості параболи запишемо вирази для MP і FD:

$$
\left\{\begin{array}{l}
M F=x+\frac{p}{2} \\
F D=\frac{p}{2}-x
\end{array}\right.
$$

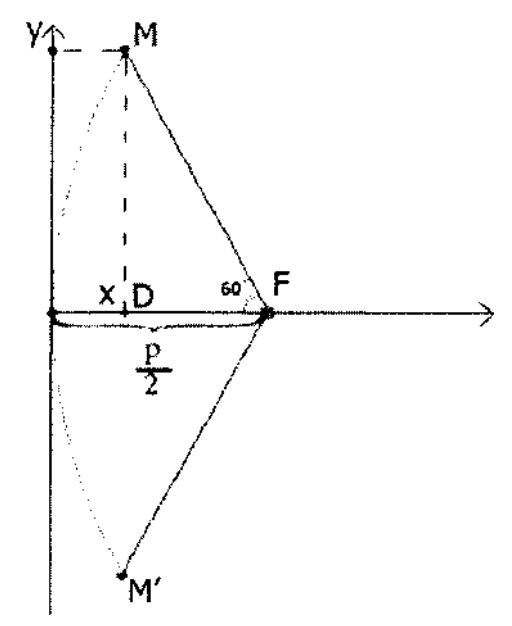

Рисунок 8 - Схема довгофокусного параболоциліндричного дзеркала 
В трикутнику $\triangle F M D$ :

$F D=M F \cos 60^{\circ}$,

$\left(x+\frac{p}{2}\right) \cos 60^{\circ}=\frac{p}{2}-x, 3 x=\frac{p}{2}$.

Робимо заміну $\frac{p}{2}$ на $3 x$ у формулі (5)

$M M^{\prime}=2\left[\sqrt{x(x+3 x)}+3 x \operatorname{arsh} \sqrt{\frac{1}{3}}\right]=2\left[x\left(2+3 \operatorname{arsh} \sqrt{\frac{1}{3}}\right)\right]$

$1200=2\left[x *\left(2+3 \operatorname{arsh} \sqrt{\frac{1}{3}}\right)\right]$

$x \approx 164,5 \mathrm{MM} ;$

$\frac{p}{2}=3 \cdot 164,5 \approx 493,5 \mathrm{MM}$

$F M=493,5+164,5=658 \mathrm{MM}$

Діаметр розкриву параболи знаходимо за формулою (3):

$M M^{\prime}=\frac{p}{2} * \frac{4 \sin 60^{\circ}}{1+\cos 60^{\circ}}=1139,5 \mathrm{MM}$.

\section{Додаткові фокусуючі спиці}

Всі параболи подібні, коефіцієнт подібності визначається ставленням фокусних відстаней. Розглянемо приклад короткофокусного рефлектора (рисунок 9). $\mathrm{FM}_{2}$ і $\mathrm{FM}_{2}$ - додаткові фокусують спиці, розташовані під кутом $60^{\circ}$ - так само, як і основні спиці у довгофокусного рефлектора. Коефіцієнт подібності дорівнює:

$k=\frac{F_{\text {Д }}}{F_{k}}=\frac{493,5}{125,5}=3,93$

$$
\begin{aligned}
& M_{2} M_{2}=\frac{M M_{\text {Д }}}{k}=\frac{1139,5}{3,93}=289,8 \mathrm{Mм} \\
& F M_{2}=\frac{F M_{\text {Д }}}{k}=\frac{658}{3,93}=167 \mathrm{MM} .
\end{aligned}
$$

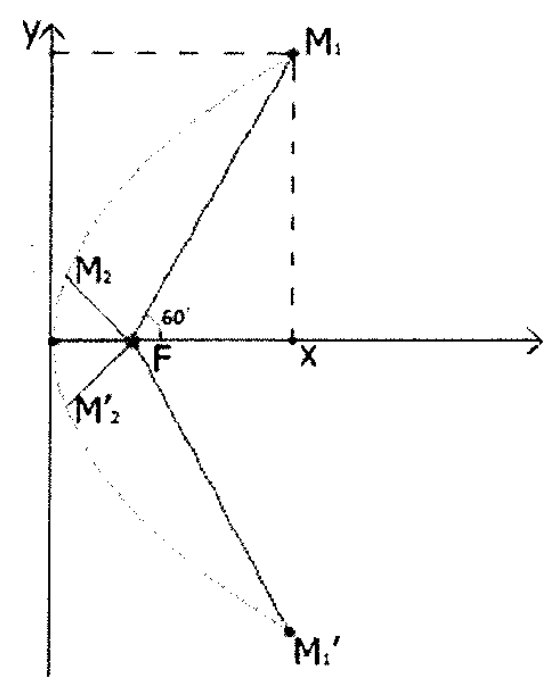

Рисунок 9 - Схема короткофокусного рефлектора

Таким же чином розраховуються додаткові фокусуючі спиці для средньофокусного і довгофокусного рефлекторів.

Результати розрахунку геометричних параметрів параболоциліндричних дзеркал наведені в таблиці 1.

Tаблиця 1 - Геометричні властивості параболоциліндричних дзеркал.

\begin{tabular}{|l|l|l|l|}
\hline \multicolumn{1}{|c|}{ Параметри, мм } & \multicolumn{1}{c|}{ Короткофокусне } & \multicolumn{1}{c|}{ Середньофокусне } & \multicolumn{1}{c|}{ Довгофокусне } \\
\hline Лінійний параметр MM' & 1200 & 1162 & 1200 \\
\hline Глибина параболи X & 376,5 & 253,1 & 164,5 \\
\hline Диаметр розкриву MM' & 869,5 & 1012,4 & 1139,5 \\
\hline Фокусна відстань F & 125,5 & 253,1 & 493,5 \\
\hline $\begin{array}{l}\text { Основна фокусуюча } \\
\text { спиця FM }\end{array}$ & 502 & 506,2 & 658 \\
\hline $\begin{array}{l}\text { Додаткова фокусуюча } \\
\text { спиця FM2 }\end{array}$ & 167 & 337,5 & - \\
\hline Апертура P & $869,5 * 600$ & $1012,4 * 300$ & $1139,5 * 600$ \\
\hline
\end{tabular}

\section{ВИСНОВКИ}

Вид описаних концентраторів дуже зручний для використання у сільській місцевості та віддалених місцях, де немає центрального газопостачання. За допомогою подібних пристроїв можна приготувати їжу, не розпалюючи багаття. Не потрібно використовувати вугілля і дрова, слідкувати за вогнищем і турбуватися про те, що хтось може постраждати від вогню. А також концентратор дуже зручний в похідних умовах. Після використання його можна скласти в простий креслярський тубус і нести в руках, або покласти в багажник машини.

\section{ЛІТЕРАТУРА}

1. Твайделл, Дж. Відновлювані джерела енергії: Пер. 3 англ. / Дж. Твайдел, А. Уейр. // - М.: Енергоатоміздат, 1990 - 392 с.: іл.

2. Бекман У. Розрахунок систем сонячного теплопостачання: Пер. $з$ англ. / У. Бекман, С. Клейн, Дж. Даффі // - М.: Вища школа, 1982. - 80 с. 
3. SOLAR COOKERS How to make, use and enjoy. $10^{\text {th }} \mathrm{ed}, 2004$. [Электронный ресурс]. Режим доступа: http://solarcookers.org.

4. Харченко Н. В. Індивідуальні сонячні установки. / Н. В. Харченко // - М.: Вища школа, 1991. - 208 с.: іл. 5. Клімачева Т. Н. 2D-креслення в AutoCAD $2007-$ 2010. Самовчитель. / Т. Н. Клімачева // - М.: ДМК Пресс, 2009. - 560 с.: іл.

6. Соколова Т. Ю. AutoCAD для студента. Самовчитель. / Т. Ю. Соколова // - СПБ.: Пітер, 2008. - 384 с.: іл.

7. Кузнєцов П. О. Організаційна надійність управління ресурсним забезпеченням при перебудові аварійних об'єктів. / П. О. Кузнєцов. / - Житлове будівництво. -2006 . - №. 1. - С. 5-6.
8. Осадчий Г. Б. Нетрадиційні варіанти хладотеплоснабженія будівель / Г. Б. Осадчий / - Технологія машинобудування. - 2004. - №. 1. - С. 50-54.

9. Осадчий Г. Б. Сонячна енергія, її похідні та технології їх використання (Введення в енергетику ВДЕ). / Г. Б. Осадчий / - Омськ: ІПК Макшеєвой Е.А., 2010. $-572 \mathrm{c}$.

10. Копилов А. С. Економічні аспекти вибору системи підтримки використання поновлюваних джерел енергії в Росії / А. Є. Копилов / - Енергетик. - 2008. № 1 - C. 7-10.

Отримана в редакції 05.02.2016, прийнята до друку 03.03.2016

D. O. Pupkov

Odessa National Academy of Food Technologies, 112 Kanatnaja str., Odessa, 65039, Ukraine

\section{THE PORTABLE PARABOLA-CYLINDRICAL SOLAR FOODSTUFFS HEATER}

Development of a parabola-cylindrical solar heater designed for heating and cooking food using solar energy is presented in the study. The design consists of a reflector, as parabola-cylindrical lens and receiver as skewers for food. Reflector is made of flexible materials but also has an advantage - resistance to external influences. Simple mount design allows to collect the heater into the drawing tube, the weight of which doesn't exceed three kilograms, making the device convenient for transportation and in use. This is a special device due to which it is possible to concentrate solar radiation in the desired point and to reach the necessary temperatures suitable for heating and cooking of foodstuffs. The heater comfortable design has been shown and calculation features of basic geometric parameters of the parabolacylindrical solar heater are given. The comparison with existing prototypes is given.

Keywords: Parabola-cylindrical; Reflector; Aperture; Solar radiation; Short-focal; Medium-focal; Length-focal.

\section{REFERENCES}

1. Twidell, G., Were, A. (1990). Vidnovliuvani dzherela energii: Per. z angl., Moscow: Energoatomizdat, 392 p.

2. Bekman, U., Kleyn, S., Daffi, G. (1982). Rozrahunok sistem sonyachnogo teplopo-stachannya: Per. z angl., Moscow, $80 \mathrm{p}$.

3. SOLAR COOKERS How to make, use and enjoy. 10th ed, 2004. [Electronic source]. Available at: http://solarcookers.org. Date of access: 14.01.2016.

4. Harchenko, H. B. (1991). Individualni soniachni ustanovki. Moscow, 208 p.

5. Klimacheva, T. N. (2009). 2D-kreslennya v AutoCAD 2007-2010. Samovchitel. Moscow: DMK Press, 560 p.

6. Sokolova, T. Yu. (2008). AutoCAD dlya studenta. Samovchitel., S.-Pb.: PIter, 384 p.
7. Kuznetsov P. O. (2006). Organizatsiina nadiynist upravlinnia resursnym zabezpechenniam pry perebudovi avariinikh obiektiv. Zhitlove budIvnitstvo. No 1, 5-6.

8. Osadchiy G. B. (2004). Netraditsiyni varianti khladoteplosnabzheniya budivel. Tekhnologiia mashinobuduvannia. No. 1, 50-54.

9. Osadchiy G. B. (2010). Soniachna energiya, ii pokhidni ta tekhnologii kih vykorystannia. (Vvedennya $\mathrm{v}$ energetiku VDE). Omsk: IPK Maksheievoi E. A., 572 p. 10. Kopilov A. E. (2008). Ekonomichni aspekty vyboru systemy pidtrymky vykorystannia ponovliuvanikh dzherel energii v Rosii. Energetik, No. 1, 7-10.

Received 05 February 2016 Approved 03 March 2016 Available in Internet 29 April 2016 